\title{
Green Criminology and Degradation of the Environment by Activities of Multinational Oil Companies in Nigeria's Niger Delta
}

\author{
Yusuf Usman \\ Department of Sociology, Kaduna State University, Kaduna, Nigeria \\ Email: Usmanyusuf126@yaoo.com
}

How to cite this paper: Usman, Y. (2021). Green Criminology and Degradation of the Environment by Activities of Multinational Oil Companies in Nigeria's Niger Delta. Open Journal of Social Sciences, 9, 317-337. https://doi.org/10.4236/jss.2021.912022

Received: October 31, 2021

Accepted: December 18, 2021

Published: December 21, 2021

Copyright ( 2021 by author(s) and Scientific Research Publishing Inc. This work is licensed under the Creative Commons Attribution International License (CC BY 4.0).

http://creativecommons.org/licenses/by/4.0/

\section{(c) (i) Open Access}

\begin{abstract}
The Niger Delta region is the hub of Nigeria's oil and gas production, which account for more than $80 \%$ of Government revenue and 95 percent of Foreign Exchange. As part of the drive for colonialism was quest for natural resources and cheap labour, so was the drive for the discovery of oil in Nigeria. Discovery of marketable oil was made in the late 50s, the finding that came with attendant consequences on the environment. The main consequence is oil spillage that has been going on for decades. The local people were not only denied their traditional means of livelihood but also not given adequate compensation. This study aims to highlight how oil spillage and oil theft has been degrading the Niger Delta environment. The study adopted a quantitative method to seek the views of some Nigerians on how long do they think the environmental degradation has been going on in the Niger Delta, and how serious or un-serious are the multinational oil companies in cleaning the environment.
\end{abstract}

\section{Keywords}

Criminology, Green Criminology, Multinational Oil Companies, Niger Delta and Environment

\section{Introduction}

Some writers agreed that the Niger Delta region's ecosystem is one of the most endangered ecosystems in the world (Anejionu et al., 2015). As a sub-discipline concerned with investigation of environment related crimes, green criminologists need to double up or even triple up effort to investigate environmental degradation in Nigeria's Niger Delta region that has been going on for more than 
50 years since the discovery of oil in the region. The environmental crimes in the region are so cruel and complex that no amount of academic investigation would completely uncover the problem. There is no disagreement about the magnitudes of environmental degradation in the region, because of acts of sabotage by individuals or operational oil spills by the multinational oil companies. It is important to acknowledge that the environmental injustice caused by oil spills in the Niger Delta region is not only due to the negligence of the multinational corporations but also the result of man-made efforts such as oil theft, bunkering, and pipeline vandalism (Odalonu, 2015). This paper seeks highlight how oil spillage and oil theft has been degrading the Niger Delta environment and to find out if multinational oil companies are responsible for degrading the Niger Delta environmental, and if they have shown more interest in cleaning the environment.

Green criminology is a sub-discipline that means different things to different persons. As argued by White (2013: p. 17) that "those who view themselves as doing green criminology define it in ways that best suit their own conception of what it is they doing". Just as there are some agreements within this sub-discipline on the major themes and problems, so also there are some disagreements on the term "green criminology". For example, White (2008) argued that "eco-global criminology" should be more appropriate while Walters (2011) suggested "conservation criminology". Michael J. Lynch first introduced the term "green criminology" in a short article in 1990, and since then, there "have been a number of fellow travelers to green criminology" (White, 2013: p. 18). Whatever any one prefers to call it and either to stay within the core discipline of criminology or interdisciplinary, the primary concern of intellectual investigation must remain on different forms of crimes as it relates to the environment especially as many are worried about global warming which Kramer (2014: p. 23) argues that "outside of a nuclear war, there is no other form of environmental crime that can produce a wide range of victims".

The pursuit for a secure supply of oil within the British Empire resulted in the search for oil possibilities in many African colonies, especially along the West Coast, because it was acknowledged that the Atlantic Ocean often washed pieces of bitumen onshore and oil seepages occurred over a wide area. The discovery of the Nigerian oil industry goes back to January 1906 when the colonial government provided various prospecting licenses to the British Colonial Petroleum Corporation, covering a territory of 100 square miles $\left(256 \mathrm{~km}^{2}\right)$ on the Rofutoro and Lafagbo Rivers in the Benin (present Edo state) region (Steyn, 2003). Concessions were further given in 1907 to the better-known Nigerian Bitumen Corporation that, somewhere in the range of 1907 and 1914, penetrated thirteen wells in the zone close Lekki Lagoon. Despite the fact that a portion of the wells yielded bitumen-stores and oil, the Corporation never prospered in exploiting their gains and went into liquidation in 1914. Traces of seepages were also discovered in some parts of Onitsha and Awka district in 1913 (Oluduro, 2014).

The initial discovery of marketable oil reserves was made in Oloibiri (present 
day Rivers State) in 1956. Two years later, oil in commercial quantity had been discovered in twelve areas of which Oloibiri, Afam and Bomu had the most promising deposits. Oil production started at Oloibiri in early 1958 with 3000 barrel per day while the Afam field was also put into production in the same year with roughly the same daily capacity as the Oloibiri field (Steyn, 2003). The first shipment of Nigerian crude oil exports (8500 tons) arrived in Rotterdam on 8 March 1958. The colonial government, in line with new developments in world oil politics in the 1950s, also passed the Petroleum Profits Tax Ordinance in 1959, in terms of which the Nigerian government obtained $50 \%$ of the profits of the oil companies (Tamuno, 2011; Civil Liberties Organisations, 1996).

Just five years of Independence, no less than nine multinational oil companies had become very active in Nigeria. These multinational oil companies are Shell-BP, Mobil, Tenneco, Texaco, Gulf (now Chevron), Safrap (now Elf), Agip, Philip and Esso. These multinational oil companies were soon joined in the late 1960s, by Japan Petroleum, Occidental, Deminex, Union Oil, Niger Petroleum and Niger Oil Resources. The peak of that period was the creation of the Nigerian National Oil Corporation (NNOC), the predecessor of the Nigerian National Petroleum Corporation (NNPC), and the admission of Nigeria into the Organisation of Petroleum Exporting Countries (OPEC) in July 1971 (Obasi, 2003: p. 1).

\section{The Niger Delta area, multinational oil companies and the environment}

From the academics, social and political commentators, there are different views, perceptions or opinions on what area is seen as Niger Delta region in Nigeria. There is an agreement among all writers and scholars that there are two classifications of definition of Niger Delta region, the geographical and the political definition. The diverse views of perceptions show part of the controversies surrounding the Niger Delta phenomenon. The political definition as given by scholars like Orogun (2010) who posits that the region known in Nigeria as Niger Delta comprises of nine states out of the 37 of the Federal Republic of Nigeria. The states of Niger Delta are Abia, Akwa Ibom, Bayelsa, Cross River, Delta, Edo, Imo, Ondo and Rivers with an estimated population of over thirty million people.

The geographical concept of Niger Delta is a geographical area in Nigeria where oil production takes place and three states made up these area Rivers, Delta and Bayelsa (Ibaba, 2011). The three (3) states are about five thousand six hundred (5600) square miles (14,400 square kilometres). The political concept comprises the three geographical Niger Delta and the neighbouring states (like Akwa-Ibom, Edo, Cross-Rivers, Imo and Ondo) where oil mining and production takes place but, in less quantity, compared to the three geographical states. Isumonah (2012) argued that the Federal Government of Nigeria used the political concept for sharing compensatory development projects in oil producing states through agencies created for that purpose like the defunct Oil Mineral Producing Areas Development Commission (OMPADEC) which lasted between the period 1992-1999 and the current agency Niger Delta Development Com- 
mission (NDDC).

Etekpe (2009) mentioned two definitions of the Niger Delta namely, historical and political. The historical include six states (Edo, Akwa Ibom, Cross-Rivers, Delta, Rivers and Bayelsa) at the time of the establishment of the Oil Producing Areas Development Commission (OMPADEC) in 1992 and nine states (Imo, Ondo and Abia plus the six mentioned earlier) at the time of the Niger Delta Development Commission (NDDC) from 2000 till date. These varied opinions of writers, researchers and commentators alike are all evidence of policy inconsistencies that is a norm in Nigeria. Whenever there is a change of government in Nigeria (and maybe some other countries of the world), there are possibilities that many of the policies of the out gone government will surely go along with that government. It also proves in the views of Achebe (2012: p. 47) how minorities of the Niger Delta try to fit "into the tripod of the largest ethnic groups that was Nigeria-Hausa/Fulani, Yoruba, and Igbo".

OMPADEC was a military government agency that acknowledged only six states as Niger Delta while NDDC is a civilian government agency that recognised nine states as Niger Delta. This study will recognise the political definition of the Niger Delta because the NDDC was established under a civilian government that has a representation of the Nigerian people unlike the historical (OMPADEC) definition that was largely more of an individual or group of friends oriented without any recourse to people concerned. Both OMPADEC and NDDC are agencies of the Federal Government of Nigeria but since OMPADEC is defunct, NDDC definition is the contemporary which is backed by the NDDC Act of 2000 and recognized by the 1999 Constitution of the Federal Republic of Nigeria. Federal Government of Nigeria created the Ministry of Niger Delta Affairs (MNDA) in 2008 that also recognise Abia, Edo, Akwa Ibom, Cross-Rivers, Delta, Rivers, Ondo, Imo, and Bayelsa as the Niger Delta states (Ministry of Niger Delta Affairs, n/d).

Briefly, the area known today as Niger Delta region consists of nine states that have oil deposits and exploration is taking place. These states are drawn from the South-South (all the six states in the zone i.e. Edo, Akwa Ibom, Bayelsa, CrossRivers, Delta, and Rivers), South-East (Abia and Imo) and South-West (Ondo) geo-political zones in Nigeria. There is a huge difference in the quantity of oil deposits between these states, while the six states under the South-South geopolitical zone have large quantity and to an extent Ondo state, the other states have less. The bulk of Nigeria's oil deposit and exploration activities is within the states of Rivers, Bayelsa, Akwa-Ibom and Delta.

The vast of Nigeria's crude oil reserves are geologically situated in the Niger Delta region which according to Orogun (2010) consists of states that are ethno-culturally diverse similar to other states that made up the federation of Nigeria. About forty indigenous groups belong to the region. Major cultural groups in the region include the Ijaws, Itsekiris, Urhobos, Isoko, Edos, Igbos, Yorubas, Ogbia, Ibibios, kalabaris, Efiks and the Ogonis. This region has confirmed crude 
oil deposits of about 24 - 31.5 billion barrels and projected 124 trillion cubic feet of natural gas. Despite this abundant wealth in natural resources, there is a complete neglect to transform the natural wealth into economic and social development in the region. The abject poverty and the growing reality of value of oil reserves has created an expression of rebellion that has turned the region into an area of violence and armed conflict (Omotola, 2009).

The discovery of oil also came with attendant consequences for the natural environment. Oil spillages are the most obvious consequences of oil exploitation and have been a problem for decades. Almost all the oil companies operating in the Niger Delta region are guilty of killing the Niger Delta environment with oil spills. The Niger Delta region is one of the most populated regions in the world, also the region's ecosystem has been declared as one of the most endangered ecosystems in the world (Anejionu et al., 2015).

Krause (2015) portrayed the problem of oil spillage as that of David versus Goliath. On one side are Royal Dutch Shell (the fourth largest company in the world) and ENI (fourth largest oil company in the Niger Delta region), Italy's biggest industrial enterprise. On the other side are the local people: forty different ethnic groups, with 70 percent of the population living below the poverty line. According to Amnesty International (2015), every year, there are hundreds of oil spills in the Niger-Delta, caused by old and poorly maintained pipelines or criminal activity such as oil theft. These spills have a devastating impact on the fields, forest and fisheries that the majority of the people depend on for their food and livelihoods. Oil spills also contaminate drinking water and expose people to serious health risks. Locals in this region have to drink, cook and even wash in a polluted water, eat fish contaminated with oil and toxins (that is in rare cases where they find a fish). The air the local communities breathe is also polluted with oil, gas and all sorts of pollutants (Tickell, 2016; Agboola et al., 2011; Mitee, 2012).

The entire Niger Delta environment is at the mercy of multinational oil companies operating in the region notably Shell, Mobil, Agip, Elf and Texaco. Contributing to the death of their own environment and a major source of their livelihood are some activities of the locals that include oil bunkering and illegal oil refinery. Getting exact figure on the frequency of oil spills in this region is very difficult but oil spills are very frequent and have been occurring for a very long period of time most especially involving Shell as the largest oil exploration company in the region. In 2014 alone, Amnesty International blamed two oil companies (Shell and Eni) for more than five hundred spills in Niger Delta (Amnesty International, 2015). Even going by the figures on Shell's official website according to Amnesty International (2015: p. 2), the amount of oil spill is tremendous as between the period of year 2007 to 2014, the company estimates that 1693 separate spills led to more than 350,000 barrels of crude oil being lost (Table 1).

A BBC reporter (Duffield, 2010) said that the environmentalists call the Delta the "global capital of oil pollution". In November 2014 during a court case in the 
Table 1. Volume of oil spilled into Niger delta environment as reported by shell.

\begin{tabular}{ccc}
\hline Year & Total number of spills & Approximate total volume in barrels \\
\hline 2007 & 320 & 26,000 \\
2008 & 210 & 100,000 \\
2009 & 190 & 120,000 \\
2010 & 170 & 23,000 \\
2011 & 207 & 18,000 \\
2012 & 192 & 22,000 \\
2013 & 200 & 20,000 \\
2014 & 204 & 22,000 \\
Total & 1693 & 351,000 \\
\hline
\end{tabular}

Source: Amnesty International, 2015: p. 3.

United Kingdom, Shell was finally forced to admit that its figures on oil spill were flawed most especially the Bodo (Ogoni area) oil spill where Shell claimed that only 100,000 barrels were spilled but an independent assessment calculated that the figure exceeded 100,000 (Duffield, 2010). Audrey Gaughran (the Director of Global Issues at Amnesty International), said that "Shell has refused to engage with us and only now that they find themselves in a UK court have they been forced to come clean" (Amnesty International, 2014). Ms Gaughran further stated that:

"In any other country, this would be a national emergency. In Nigeria it appears to be standard operating procedure for the oil industry. The human cost is horrific, people living with pollution every day of their lives" (Gaughran cited in Amnesty International, 2014: p. 9).

Following the legal action in the UK, in January 2015 Shell was forced to accept responsibility and the company agreed an out-of-court settlement of $\$ 84$

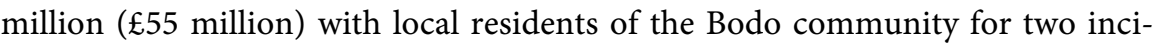
dents of oil spills in 2008. In one of its Press Releases titled "Nigeria: Alarming number of oil spills blight Niger Delta", Gaughran through Amnesty International (2015: p. 5) also captured the Bodo case this way:

"If all oil spills could be scrutinised the way the two Bodo spills were then the true scale of the damage and Shells financial liabilities would be revealed. But this is not only about liabilities-there is a very serious human issue. Shell is cheating people out of just compensation. The Bodo case makes it clear just what it takes to get this company to own up to the truth about oil spills, six years and the UK court proceedings. What about all the hundreds of other communities this company has potentially cheated?"

In the particulars of the claim documents submitted on the $23^{\text {rd }}$ March 2012 to the High Court of Justice Queens Bench Division, the Bodo community (also referred to as claimant in the documents) is a Nigerian fishing dependent com- 
munity of about 49,000 inhabitants that comprises of 35 villages that are under Gokana Local Government area of Rivers State. The community is said to be located on the North East edge of creeks and mangrove wetlands also known as Bodo creek that comprises of about 9230 hectares of land, swampland and waterways (the creeks). There are two oil flow stations operated by Shell within the Bodo community. The defendant was reported to have carried out oil exploration and exploitation in the area since 1994 but the area remains extremely vulnerable to oil spills. The Bodo community has had only minor cases of oil spills from neighbouring communities before the occurrence of this and the creeks were ecologically sound (Bodo v Shell court documents, 2012).

The Bodo v Shell court documents (2012) also provide details that include the applicable law under which the claimant brought the case to the UK as well as factual basis for the claim. Croft (2017) argues that the case against Shell is brought to the UK because the local people do not have confidence in the Nigerian judicial system as similar cases have been delayed for many years.

In March 2016, Shell was slammed with another fresh environmental claim in the London High Court from two communities who said they were severely affected by the repeated large scale of oil spills from the company's pipelines. The two communities are Ogale and Bille, both in Rivers State. According to Amnesty International (2015), Shell repeatedly put the blame for the oil spills on illegal activities in the Niger Delta but court documents revealed that internal emails and reports showed that some senior employees of the company had expressed worry as far back as in year 2001 of the need to change oil pipelines in the Niger Delta region.

Omoregie (2016), Iguh (2016) and Amnesty International (2014) were of the view that the activities of this oil companies have not been positive to both the people inhabiting the region or their environment. There are devastating effects of oil on their environment and this is mainly attributed to oil spillage due to negligence of the oil companies and sometimes due to acts of sabotage by the locals. Oil spillages have completely denied the locals their traditional means of livelihood which is farming. Their farmlands and waters are nothing but oil which is not only dangerous to their health but also to their environment.

Impacts of oil spills on the Niger Delta people and the environment

The companies in the region are not only committing an environmental crime against communities but against humanity. This point is strongly expressed by Mitee (2012) who stated that

"it would be safe, therefore, to assert that in the hierarchy of rights, the rights to a secure and protected environment is first amongst equals. It is for this reason we assert that the egregious and pervasive violation of environmental rights in the quest for oil should be elevated to the pedestal and punished as crimes against nature, similar in gravity to crimes against humanity" (Mitee, 2012: p. 8).

While there is abundant literature on oil spillages by the oil companies in the Niger Delta region, surprisingly, there is little independent scientific data on the long-term effects of oil spills on the host communities (Mitee, 2012). Amnesty 
International (n/d); Steve (2007); Asuni (2009); Ellis (2016) and Adewale (1989) talk about oil spills in the Niger Delta region and its impacts on the communities. The impacts of oil spills can be enormous which can affect coastal ocean ecosystems, human health and the economy as seen in the Gulf of Mexico oil spill in 2010 (Frost, 2014). Nigeria is reported to have a history of catastrophic oil spills that have wreaked havoc on the environment and the host communities (Gaffey, 2017).

A commonly cited scientific report is that of the United Nations Environment Programme (UNEF) of 2011 that carried out two years environmental assessment of Ogoniland. The findings of the UNEF are categorized into vegetation, aquatic, public health, institutional issues and oil industry practices. Among its findings on vegetation, the UNEF (2011: p. 10) shows that when oil is spilled on lands, fires regularly break out and kill vegetation and create a crust over the land which makes revegetation very difficult. On aquatic ecosystems, the research discovered that the surface water throughout the whole creeks contains hydrocarbons whose moving layers vary from heavy black oil to thin shines. In addition, on public health, the research pronounces that

"of most immediate concern, community members at Nisisoken Ogale are drinking water from wels that is contaminated with benzene, a known carcinogen, at levels over 900 times above the World Health Organization (WHO) guideline. The report states that this contamination warrants action ahead of all other remediation efforts" (UNEF, 2011: p. 11).

Human health wise, the impact of oil spills in the Niger Delta region on generation, yet unborn could only be imagined (UN Environment, 2017). According to Bruederle and Hodler (2017), the first to investigate the causal effects of onshore oil spills on neonatal and infant mortality rates and child health, find that oil spills double the neonatal mortality rate in the region. The study was a scientific inquiry on the effects of nearby oil spills that occurred prior to a child's conception or during pregnancy. The empirical strategy relied on sibling comparisons i.e. they compare mortality rates of infants of the same mothers, some conceived before the first nearby oil spill and some conceived thereafter. The conclusion of the study is that oil spills in the Niger Delta region could kill 16,000 babies a year.

The worrying part of the UNEF report is the assumption that it will take almost 30 years to clean oil spills from the Niger Delta region (UNEF, 2011: p. 12). Oil theft is a contributory factor to oil spilled in the Niger Delta region, but oil companies remain the main culprits of the spills. Shell and Eni are the two major companies with the highest cases of oil spill in the Niger Delta region, the two companies spilt almost 21.7 million litres of oil into the environment between 2011-2017 (Amnesty International, 2018). Gas flaring is also another means at which the oil companies are destroying the Niger Delta environment.

Gas flaring refers to the burning of associated gas that goes with the extraction of crude oil from oil fields during oil drills. It is the means by which excess natural gas is let loose from oil wells and burned into the air (Iguh, 2016: p. 1). The 
second destroyer of the Niger Delta environment is gas flaring. This has been a recurrent problem since the beginning of oil exploration in Nigeria. According to Climate Justice Programme (2005: p. 4), there is more gas flaring than anywhere else across the globe. The country still allows gas flaring despite being a signatory to the Global Gas Flaring Initiative that is championed by the World Bank. Estimates are extremely untrustworthy, it is roughly estimated that about 2.5 billion cubic feet of gas associated with crude oil are flared every day. This estimate is equivalent to about 40 percent of Africa's entire natural gas consumption in 2001 (Friends of the Earth International, 2005).

All the oil exploration companies operating in the Niger Delta are guilty of gas flaring, the main perpetrators are the three major companies discussed above. Other minor perpetrators are Total and Agip. For over ten years, the three main perpetrators have made promises to end gas flaring, but no tangible steps have been taken to show their readiness in ending it despite Nigerian Government and Court orders (Friends of the Earth International, 2005, 2007; Omoregie, 2016).

Gas flaring in the view of Agboola et al. (2011: p. 69) is not an accident, but a deliberate attempt to cut cost at the detriment of the host communities and the Niger Delta environment. The authors argued that because the oil companies are profit oriented, they care less for the Nigerian people and the environment. To flare the gas is much cheaper to the oil companies than to convert it to domestic use. One is tempted to ask if there are no regulatory agencies in the Nigerian oil and gas sector that will ensure implementation of laid down rules and regulations. The Climate Justice Programme concludes that

"it is a story of appalling carelessness, greed, corruption, double standards and environmental racism. Perhaps, above all, it is a story of serial, cumulative and shameful failure, on the part of British colonialism, the oil companies and the Nigerian ruling elite" (Climate Justice Programme, 2005: p. 5).

\section{Theoretical Framework}

The man-made efforts (oil theft, bunkering, and pipeline vandalism) are often the cause of local residents who are expressing their frustration on the oil companies for not developing their land. The frustration-aggression theory which advocates that blocked opportunities may result in deviancy (Dollard, Miller, Doob, Mowrer, \& Sears, 1939) is explored to buttress this argument. In the views of Dollard et al. (1939), frustration refers to condition which occurs when a goalresponse suffers intrusion, while aggression means an act whose goal-response is injury to an organism.

The basic tenets of the frustration-aggression theory is that when efforts or means to peacefully achieve goal (s) is denied or prevented, frustration occurs which can produce feelings of rage that can turn into exhibition of aggressive behaviour and violence. While the frustration-aggression theory has been applied to provide an insight in understanding violent behaviour over time, it is accused of overgeneralization in its assumptions. 
Means to earn a living is among the primary goals of every sane person and when these means are denied, there could be frustration. As mentioned earlier, farming has been the primary means of livelihood for the people of the Niger Delta region before the discovery of oil. The discovery of oil came along with it companies whose activities has led to the death of almost all of the farmlands in the region (Agboola et al., 2011; Anejionu et al., 2015; Omoregie, 2016). Left with minimal, or perhaps, complete absence of other means of livelihood, some youths and elders in the region were forced to engage in illegal and dangerous activities like oil theft or oil bunkering, pipeline vandalization, illegal oil refinery and others. They don't mind the negative consequences of their activities on the environment, probably, because there is nothing left to them to care for.

\section{Data and Methodology}

This study adopts quantitative method that is ideally suited for finding answers to questions like who did what? What is the motive? When and where does it happened? Jupp (2006) said quantitative research produces "points" about the world and behaviour which are viewed as adding to the sum of human knowledge. Since it is not possible for this study to seek the opinion(s) of the entire Nigerian populace, there is a need to select a part of it and hence, sampling. Sampling according to Robson (2002: p. 260) is an important part of enquiry in a study. Sampling is taking a part out of a whole population. The study also used data from other sources like available records from organisations.

In the study by Usman (2017) on the renewal of 2016 militant activities in Nigeria, self-administered questionnaires were evenly distributed in each of the six geopolitical zones. The questionnaires were disseminated in hard copies (paper based) amongst some randomly selected educated Nigerians because of the assumption that they could have an in-depth and up-to-date knowledge of events relating to the Niger Delta. Such knowledge could have been acquired through the various sources of information like media or formal education in any of the institutions of higher learning where "General Studies" (GNS) courses (modules) are taught. It is also anticipated that educated participants would be more ready to participate in the research because they know its importance. Another reason for targeting educated Nigerians was to utilize time, administering a questionnaire on an un-educated individual takes a lot of time as the questions need to be read to him/her.

Respondents were randomly selected from University students and lecturers by research assistants. The respondents were cordially approached by the assistants (who are lecturers), who after explaining what the research is all about, gave out the self-administered questionnaires and asked to return them within three days to their class representatives (elected representatives of the students). For the lecturer respondents, they were politely asked to drop it with the secretary of their various departments. Students and lecturers in five departments were contacted for easy retrieval of the questionnaires. 
The study was guided by the Bangor University (BU) Research Ethics guidelines. The Bangor University College of Business, Law, Education and Social Sciences (CBLESS) ethics committee reviewed and gave approval to proceed to fieldwork. Conformity with other important professional bodies research ethical guidelines such as the Statement of the Ethical Practice for the British Sociological Association (BSA, 2002) and the British Society of Criminology's Statement of Ethics (BSC, 2015) was insured. To ensure the anonymity of the respondents, use of name was avoided and instead, codes were assigned to each respondent. Any risk to participants and to the researcher was carefully considered.

\section{Results}

While it is a fact that illegal militant activities like oil theft and oil bunkering contributes immensely to the environmental degradation in the region, operational spills by the oil companies contribute more. Mr Justice Aikenhead ruled in the Bodo court case in 2014 that failure of Shell to take realistic steps to look after, maintain or repair its infrastructure, could make the company liable to pay for oil spills resulting from illegal oil stealing from its oil pipelines (Amnesty International, $\mathrm{n} / \mathrm{d}$ ).

There is a significant difference in answers across the six geopolitical zones to the question whether oil companies are responsible for environmental degradation. In Northcentral 46\% answered "strongly agree" and 40\% "agree", Northeast $33.3 \%$ "strongly agree" and $52.1 \%$ "agree", Northwest $36.2 \%$ "strongly agree" and $48.9 \%$ "agree", Southeast $48 \%$ "strongly agree" and 34\% "agree", Southsouth $42.9 \%$ "strongly agree" and 31\% "agree", and in Southwest 16\% "strongly agree" and $46 \%$ "agree". The result tells us that even the Northern regions that experience no direct impact of environmental degradation because of activities of oil companies share their views with those directly impacted in the Southern region. There is widespread agreement among respondents that the Niger Delta environment is at the mercy of the oil companies.

The Niger Delta in the views of Friends of the Earth International (2007) is the fifth most oil polluted habitation on the globe with the equivalent of 50 Exxon Valdez's already spilt by 2006 in the region. On the duration of environment degradation, many of the respondents indicate that the Niger Delta environment has been degraded for more than twenty years (Table 2) and oil companies are responsible for the environmental degradation (Table 3).

While it is a fact that militant activities like oil theft and oil bunkering contributes greatly to the environmental degradation in the region, operational spills by the oil companies contribute more. Mr Justice Aikenhead ruled in the Bodo court case in 2014 that failure of Shell to take realistic steps to look after, maintain or repair its infrastructure, could also make the company liable to pay for oil spills resulting from illegal oil stealing from its oil pipelines (Amnesty International, n/d).

There is a significant difference in answers across the six geopolitical zones to the question whether oil companies are responsible for environmental degradation. In Northcentral $46 \%$ answered "strongly agree" and 40\% "agree", Northeast 
Table 2. Years of environmental degradation.

\begin{tabular}{ccccccc}
\hline $\begin{array}{c}\text { Geopolitical } \\
\text { zones }\end{array}$ & $\begin{array}{c}\mathbf{5 - 1 0} \\
\text { Years }\end{array}$ & $\begin{array}{c}\mathbf{1 1 - 2 0} \\
\text { Years }\end{array}$ & $\begin{array}{c}\mathbf{2 1 - 3 0} \\
\text { Years }\end{array}$ & $\begin{array}{c}\mathbf{3 1 - 4 0} \\
\text { Years }\end{array}$ & $\begin{array}{c}\text { Above } \\
\text { 40 Years }\end{array}$ & Number \\
\hline Northcentral & $2.0 \%$ & $14.0 \%$ & $32.0 \%$ & $26.0 \%$ & $26.0 \%$ & 50 \\
Northeast & $14.6 \%$ & $20.8 \%$ & $27.1 \%$ & $25.0 \%$ & $12.5 \%$ & 48 \\
Northwest & $8.5 \%$ & $19.1 \%$ & $27.7 \%$ & $19.1 \%$ & $25.5 \%$ & 47 \\
Southeast & $6.0 \%$ & $18.0 \%$ & $16.0 \%$ & $26.0 \%$ & $34.0 \%$ & 50 \\
Southsouth & $4.8 \%$ & $16.7 \%$ & $31.0 \%$ & $23.8 \%$ & $23.8 \%$ & 42 \\
Southwest & $14.0 \%$ & $36.0 \%$ & $24.0 \%$ & $12.0 \%$ & $14.0 \%$ & 50 \\
Total & $8.4 \%$ & $20.9 \%$ & $26.1 \%$ & $22.0 \%$ & $22.6 \%$ & 287 \\
\hline
\end{tabular}

Source: fieldwork 2017

Table 3. Oil companies responsible for environmental degradation.

\begin{tabular}{ccccccc}
\hline $\begin{array}{c}\text { Geopolitical } \\
\text { zones }\end{array}$ & $\begin{array}{c}\text { Strongly } \\
\text { agree }\end{array}$ & Agree & Disagree & $\begin{array}{c}\text { Strongly } \\
\text { disagree }\end{array}$ & $\begin{array}{c}\text { Not } \\
\text { sure }\end{array}$ & Number \\
\hline Northcentral & $46.0 \%$ & $40.0 \%$ & $10.0 \%$ & $2.0 \%$ & $2.0 \%$ & 50 \\
Northeast & $33.3 \%$ & $52.1 \%$ & $6.3 \%$ & $2.1 \%$ & $6.3 \%$ & 48 \\
Northwest & $36.2 \%$ & $48.9 \%$ & $8.5 \%$ & $2.1 \%$ & $4.3 \%$ & 47 \\
Southeast & $48.0 \%$ & $34.0 \%$ & $4.0 \%$ & $4.0 \%$ & $10.0 \%$ & 50 \\
Southsouth & $42.9 \%$ & $31.0 \%$ & $4.8 \%$ & $2.4 \%$ & $19.0 \%$ & 42 \\
Southwest & $16.0 \%$ & $46.0 \%$ & $12.0 \%$ & $10.0 \%$ & $16.0 \%$ & 50 \\
Total & $36.9 \%$ & $42.2 \%$ & $7.7 \%$ & $3.8 \%$ & $9.4 \%$ & 287 \\
\hline
\end{tabular}

Source: fieldwork 2017.

33.3\% "strongly agree" and 52.1\% “agree", Northwest 36.2\% "strongly agree" and $48.9 \%$ "agree", Southeast 48\% "strongly agree" and 34\% "agree", Southsouth 42.9\% "strongly agree" and 31\% "agree", and in Southwest 16\% "strongly agree" and $46 \%$ "agree". The result tells us that even the Northern regions that experience no direct impact of environmental degradation because of activities of oil companies share their views with those directly impacted in the Southern region. There is widespread agreement among respondents that the Niger Delta environment is at the mercy of the oil companies.

The result (Table 4) shows that despite these long years of degrading the Niger Delta environment, unfortunately the oil companies have shown little interest in cleaning-up the environment according to majority of the respondents, "strongly agree" and "agree" answers are more frequent in all the six geopolitical zones.

Most of the regulatory agencies in the industry like the "Department of Petroleum Resource" and others lack both the liberty and wealth needed to "regulate the very sophisticated operations in the oil industry" (Soremekum, 2011: p. 106).

Having made a good effort by imposing a fine on Shell, the National Oil Spill Detection and Response Agency's (NOSDRA) main challenge according to the 
International Crisis Group (2015: p. 12) remains inadequate professional personnel and facilities, as the agency depend greatly on "almost everything from logistics to collection of soil and water samples from impacted areas on voluntary cooperation and support from oil companies and facility owners who are often reluctant to help it assess damage they may have caused".

Most of the respondents (Table 5) "agree" that regulatory agencies in the oil and gas sector are not doing much to ensure multinational oil companies clean-up the Niger Delta environment. Overall, "strongly agree" answer is $27.6 \%$ while "agree" answer is $43.4 \%$ and "not sure" $16.4 \%$. Scepticism could be a reason for the responses in the Northcentral.

Summarily, the majority of the respondents expressed views, which corroborate Vidal's (2013) that oil companies are regarded as primarily responsible for environmental degradation of the Niger Delta region. The result further supports the view that regulatory agencies like the NOSDRA and interventionist agencies like the NDDC have failed to fulfill their mandates of ensuring that oil companies clean up the environment.

Table 4. Oil companies shown little interest in cleaning up the environment.

\begin{tabular}{ccccccc}
\hline $\begin{array}{c}\text { Geopolitical } \\
\text { zones }\end{array}$ & $\begin{array}{c}\text { Strongly } \\
\text { agree }\end{array}$ & Agree & Disagree & $\begin{array}{c}\text { Strongly } \\
\text { disagree }\end{array}$ & $\begin{array}{c}\text { Not } \\
\text { sure }\end{array}$ & Number \\
\hline Northcentral & $34.0 \%$ & $32.0 \%$ & $18.0 \%$ & $4.0 \%$ & $12.0 \%$ & 50 \\
Northeast & $20.8 \%$ & $52.1 \%$ & $0.0 \%$ & $6.3 \%$ & $20.8 \%$ & 48 \\
Northwest & $25.5 \%$ & $48.9 \%$ & $10.6 \%$ & $2.1 \%$ & $12.8 \%$ & 47 \\
Southeast & $32.0 \%$ & $44.0 \%$ & $12.0 \%$ & $4.0 \%$ & $8.0 \%$ & 50 \\
Southsouth & $11.9 \%$ & $52.4 \%$ & $7.1 \%$ & $9.5 \%$ & $19.0 \%$ & 42 \\
Southwest & $14.0 \%$ & $46.0 \%$ & $18.0 \%$ & $6.0 \%$ & $16.0 \%$ & 50 \\
Total & $23.3 \%$ & $45.6 \%$ & $11.1 \%$ & $5.2 \%$ & $14.6 \%$ & 287 \\
\hline
\end{tabular}

Source: fieldwork 2017.

Table 5. Regulatory agencies not doing much to make oil companies clean up the environment.

\begin{tabular}{ccccccc}
\hline $\begin{array}{c}\text { Geopolitical } \\
\text { zones }\end{array}$ & $\begin{array}{c}\text { Strongly } \\
\text { agree }\end{array}$ & Agree & Disagree & $\begin{array}{c}\text { Strongly } \\
\text { disagree }\end{array}$ & $\begin{array}{c}\text { Not } \\
\text { sure }\end{array}$ & Number \\
\hline Northcentral & $48.0 \%$ & $42.0 \%$ & $2.0 \%$ & $2.0 \%$ & $6.0 \%$ & 50 \\
Northeast & $22.9 \%$ & $50.0 \%$ & $12.5 \%$ & $2.1 \%$ & $12.5 \%$ & 48 \\
Northwest & $23.4 \%$ & $53.2 \%$ & $2.1 \%$ & $2.1 \%$ & $19.1 \%$ & 47 \\
Southeast & $32.0 \%$ & $46.0 \%$ & $12.0 \%$ & $2.0 \%$ & $8.0 \%$ & 50 \\
Southsouth & $26.8 \%$ & $34.1 \%$ & $7.3 \%$ & $2.4 \%$ & $29.3 \%$ & 42 \\
Southwest & $12.0 \%$ & $34.0 \%$ & $14.0 \%$ & $14.0 \%$ & $26.0 \%$ & 50 \\
Total & $27.6 \%$ & $43.4 \%$ & $8.4 \%$ & $4.2 \%$ & $16.4 \%$ & 287 \\
\hline
\end{tabular}

Source: fieldwork 2017. 


\section{Analysis and Discussion}

On environmental degradation, the activities of the two companies Shell and Eni, remain the major killers of the Niger Delta environment (Amnesty International, 2015). The findings revealed that regulatory agencies like NOSDRA and NESREA could not do much to make oil companies like Shell clean up the environment because the agencies rely on Shell and others for most of the technical expertise needed to measure and examine impact (s) of oil spill (United Nations Environment Programme, 2011). Although the NOSDRA claimed to have contracted independent international experts on the Bodo oil spill that led to the Shell being fine $\$ 3.6$ billion. Is it not an irony that Shell or any other oil company operating in the Niger Delta region is rely upon to give technical expertise to determine the extent of crime committed in order to penalize the company? The study discovered that regulatory agencies are not doing enough to make oil companies clean up the environment.

In 1996, the Niger Delta Environmental Survey (NDES) was set up to "reconcile industry, environment and community interests in the Niger Delta." (Imevbore \& Gundlach 1997: p. 1). This is a brainchild of Shell which Civil Liberties Organisations (1996: p. 15) refers to as "fraud", on the surface looks "laudable venture" but "Shell is not sincere in it because there is a lengthy hidden agenda which is revealed by scrutiny of the steering committee's Terms of Reference and Shell's Briefing note". The NDES amid others wishes to avert attention of the host communities from further demanding Shell to provide community development projects. Instead, "the survey is to lay emphasis on other sources of environmental degradation" (Civil Liberties Organisations, 1996: p. 15), and "apportion degrees of blame and responsibilities amongst culprits" (NDES Chairman Gamaliel Onosode cited in Civil Liberties Organisations, 1996: p. 15).

The NDES exercise ended up in series of controversies and accusations of insincerity by both the Shell and government that led to a stalemate. In an attempt to sail across from stand-off to action, in 2007, the government in consultation with other stakeholders in the oil and gas sector, invited the United Nations Environment Programme (UNEP) to "consider an assessment of oil pollution in Ogoniland" (UNEP, 2011: p. 6; Shoraka \& Emmanuel, n/d). According to the UNEP, the assessment covers "contaminated land, groundwater, surface water, public health, industry practices and institutional issues" (UNEP, 2011: p. 8). At the end of the assessment, UNEP concludes that "the environmental restoration of Ogoniland is possible but may take 25 to 35 years", the report contains several recommendations that "once implemented, will have an immediate and positive impact on Ogoniland" and will bring long-lasting developments for the local communities and the country in general (UNEP, 2011: p. 12). The UNEP is also accused of being partial towards "Shell who funded the study as they had taken information from government figures supplied by oil company data" (Shoraka \& Emmanuel, n/d, p. 10). This study revealed that oil companies have shown little interest in cleaning the Niger Delta environment.

The study revealed just like Vidal (2013) that oil companies are primarily re- 
sponsible for environmental degradation of the Niger Delta region and these has been occurring for about forty years now. Continuous pollution of the Niger Delta environment is equal to continuous abuses of the people's human rights. This is contained in the 1972 United Nations Conference on the Human Environment which stated that "man has the fundamental right to freedom, equality and adequate conditions of life, in an environment of a quality that permits a life of dignity and well-being, and he bears a solemn responsibility to protect and improve the environment for present and future generations" (United Nations, 1972: p. 4). Pollution of the Niger Delta environment did not begin in recent time but in the early stage of oil exploration by Shell. Unfortunately, Shell has not only earned a bad reputation among its host communities but even some of its staff. The head of Environmental studies for Shell in Nigeria, Bopp Van Dessel, voluntarily left his job in 1994 expressing dissatisfaction he felt because he is "unable to defend the company's environmental record without losing his personal integrity" (cited in Amnesty International, 2018: p. 11).

Despite the activities of the Niger Delta militants like oil bunkering and illegal refineries contributing to the environmental degradation, theirs remain far less amount compared to that of the oil companies. The environment remains the primary source of the people's means of livelihood because they are mainly farmers and fishermen/women, and by killing their environment, these means have been denied which further make life difficult for them. By denying them the means of their living, it is expected that the oil companies will put in place some measures through corporate social responsibility to ameliorate their sufferings. Pathetically, the people remain in abject poverty despite what the claims of corporate social responsibility by the oil companies.

The study's findings contradict the claims of doing much in terms corporate social responsibility by the oil companies. Corporate social responsibility in the midst of frequent operational oil spills into the Nige Delta environment. Whenever confronted with the unfriendly attitudes towards the people and the community, Shell is fast to point out that none of its competing companies or even government has delivered community projects matching its efforts in Ogoniland. What Shell always fail to mention argued Civil Liberties Organisations (1996: p. 15) is that it is "also the oldest and largest exploiter of the people's resources". Type of Shell's corporate social responsibility in Nigeria is nothing more "than just window-dressing" (Mehra, 2012: p. 2). The hazards Shell created by far overshadow what it has provided to safeguard human life in Niger Delta region, perhaps, this is what made researchers like Sanchex (2016) to believed that the corporate social responsibility in the oil and gas sector is a paradox. Asaju (2012: p. 1) also argued that corruption is enshrined in the Deoxyribonucleic acid (DNA) of government officials (elected and appointed), it is clearly impossible for businesses to clean up because what they usually would leave as CSR is not the traditional thing but "corrupting social responsibility" given to individuals or because of individuals and not for communal benefit.

To be fair to Shell, it appears the company is putting in resources in the Niger 
Delta to better the people's condition, but how genuine and committed is Shell bearing in mind that the case of Gokana General Hospital and supply of expired drugs to the hospital (U.S. Non-Governmental Delegation Trip Report, 1999). Because the oil companies are not doing much to develop the Niger Delta region, much is expected from the Federal government and hence creation of interventionists agencies saddled with responsibilities to develop the region.

\section{Suggestions}

There is an urgent need for the Federal government to provide regulatory agencies like NOSDRA and NESREA with the necessary technical knowhow to independently investigate, monitor and prosecute any oil company that fails to obey the environmental guidelines as established by relevant laws of the country. It is assumed that no company owns a nation except a nation that deliberately decide to turn a blind eye to bad governance by submitting itself to powerful companies that dictate what to do and what not to do. The Nigerian government must endeavour to redeem itself by denouncing that it is not answerable to Shell, and among the means of doing this is to ensure that Shell or any other oil company never gets away with any convicted crime by monitoring their manoeuvring of the Nigeria justice system.

The activities of "militant cum" pirates on the coast of Gulf of Guinea is growing at a disturbing pace as acknowledged by the United Nations Office on Drugs and Crime (2013). Nigeria is losing millions of dollars through oil bunkering or oil theft that is mostly transported through the sea to be sold at black markets. Arms trafficking and human trafficking is very rampant as well on coast of Gulf of Guinea. Nigeria is a major energy supplier to the West, therefore, the government should develop a collaborative framework with international allies to fight arms trafficking, pirates' acts and other marine related crimes on the coast of Guinea. It is now inactive but the "Gulf of Guinea Energy and Security Strategy" created in 2005 needs to be revived. The strategy drew together Nigeria, United States of America, Britain, Canada, Netherlands, Norway, Switzerland and Gulf of Guinea States.

As a company with global representation, it is important for Shell to realise that been unethical in dealing with its host communities and employees may have negative consequences in future. This may include exposing the company's covert management meetings and policies by its employee; example is the case of an ex-employee Dr John Huong, Shell Malaysian Geologist who threatened to blow the whistle on management offences that includes fraudulent increase of hydrocarbon reserves and putting staff's lives at risk because of lax safety procedures. It took the combined efforts of eight of the company's subsidiaries to sue the Geologist from stopping him to blow the whistle, he was stopped by series of court injunctions "before settling the entire litigation out of court" (Donovan, 2011: p. 1). The fate of Shell business in Malaysia can only be imagine if by chance Dr John Houng becomes the leader of Malaysia in future.

Presently, it is doubtful if Shell's operation will survival in the Niger Delta re- 
gion without the use of force that is consuming lots of money on manned security to be able to carry on its business. The oil companies carelessly created the hostile atmosphere. As revealed by Adeniyi, if President Umaru Musa Yar'adua had lived to this time, I am not sure how tense will Shell be in dealing with him and the politicians that the company accused of wanting to buy missiles for the militants to destroy the company's oil facilities. Shell according to Adeniyi (2011: p. 45) had found relating with President Umaru Musa Yar'adua difficult because he had expressed his unhappiness for the company's "disrespect for constituted authority". It is recommended that all the oil companies especially Shell should reconsider some of their activities that have over the years given them bad names in the eyes of both the host communities and other Nigerians. It is a possibility that a Nigerian with Nationalist and radical views may be the president of the country and it could not be business as usual with the oil companies.

\section{Conclusion}

Compensation must be paid to the communities for the resources lost because of the oil exploration and for failure to replace long overdue oil pipelines. There is no justification for any oil company operating in Nigeria to take advantage of the corrupt system by disregarding constituted authority. Going by history, oil companies need to bear in mind that a confirmed crime that is unpunished today in Nigeria does not mean that it will never be punish tomorrow in another part of the world. Examples include series of on-going litigation against Shell, Eni and others across different European countries. The oil companies need to be more transparent, open their doors to independent bodies to monitor or verify any questionable activity especially as relates to environmental degradation and their dealings with the host communities. The companies must also end the use of Nigerian security personnel to suppress any peaceful protest against their activities.

As long as the government continues to romance with the oil companies and ignore the plight of the Niger Delta people, the oil companies will continue to manoeuvre the Nigeria laws to suit their greedy business interest of exploitation by further degrading the environment. If the government decides to do the right thing, collaborating with its international allies will be an appropriate option that may likely compel the oil companies to respect the rights to life of the people by stopping the killing of the environment. The government can appeal to the United Nations to draw the attention of countries of origins of the oil companies to respect not just the host communities' environments but also the global efforts of fight against global warming.

\section{Conflicts of Interest}

The author declares no conflicts of interest regarding the publication of this paper. 


\section{References}

Achebe, C. (2012). There Was a Country: A Personal History of Biafra. Penguin Group.

Adeniyi, O. (2011). Power, Politics and Death: A Front-Row Account of Nigeria under the Late President Yar'Adua. Kachifo Limited.

Adewale, O. (1989). Oil Spill Compensation Claims in Nigeria: Principles, Guidelines and Criteria. Journal of African Law, 33, 91-104. https://doi.org/10.1017/S0021855300008019

Agboola, O. M., Nwulu, I. N., Egeliolu, F., \& Agboola, O. P. (2011). Gas Flaring in Nigeria: Opportunity for Household Cooking Utilization. International Journal of Thermal and Engineering, 2, 69-74. https://doi.org/10.5383/ijtee.02.02.002

Amnesty International (2014). Nigeria: Hundreds of oil spills continue to blight Niger Delta.

https://www.amnesty.org/en/latest/news/2015/03/hundreds-of-oil-spills-continue-to-bl ight-niger-delta/

Amnesty International (2015). Clean It up: Shell's False Claims about Oil Spill Response in the Niger Delta.

Amnesty International (2018). Nigeria: Amnesty Data Activists Uncover Serious Negligence by Oil Giants Shell and Eni.

https://www.amnesty.org.uk/press-releases/nigeria-amnesty-data-activists-uncover-seri ous-negligence-oil-giants-shell-and-eni

Amnesty International (n.d.). Briefing for Investors, Shell's Growing Liabilities in the Niger Delta: Lessons from the Bodo Court Case.

https://www.amnesty.org.uk/files/amnesty international briefing on shell for invest ors.pdf

Anejionu, O. C. D., Ahiarammunnah, P. N., \& Nri-Ezedi, C. J. (2015). Hydrocarbon Pollution in the Niger Delta: Geographies of Impacts and Appraisal of Lapses in Extent Legal Framework. Resources Policy, 45, 65-77.

https://doi.org/10.1016/j.resourpol.2015.03.012

Asaju, T. (2012). Wakaman. Sunday Trust Newspaper.

Asuni, J. B. (2009). Working Paper on Understanding the Armed Groups of the Niger Delta. The Council on Foreign Relations.

Bodo v Shell Court Documents (2012). The Bodo Community, Gokana Local Government Area, Rivers State, Nigeria (Claimant) and the Shell Petroleum Development Company of Nigeria Ltd (Defendant): Particulars of Claim. Platform London Organisation.

http://platformlondon.org/wp-content/uploads/2012/06/The-Bodo-Community-and-T he-Shell-Petroleum-Development-Company-of-Nigeria-Ltd.pdf

British Society of Criminology (2015). British Society of Criminology Statement of Ethics 2015. https://www.britsoccrim.org/documents/BSCEthics2015.pdf

British Sociological Association (2002). Statement of Ethical Practice for the British Sociological Association.

https://www.britsoc.co.uk/media/23902/statementofethicalpractice.pdf

Bruederle, A., \& Hodler, R. (2017). The Effect of Oil Spills on Infant Mortality: Evidence from Nigeria. CESifo Working Paper No. 6653.

http://www.cesifo-group.de/DocDL/cesifo1 wp6653.pdf

https://doi.org/10.2139/ssrn.3043605

Civil Liberties Organisations (1996). Ogoni: Trials and Travails.

Climate Justice Programme (2005). Gas Flaring in Nigeria: A Human Rights, Environ- 
mental and Economic Monstrosity.

Croft, J. (2017). Shell Wins Legal Fight over Niger Delta Oil Spills. Financial Times. https://www.ft.com/content/5c734506-aae4-3d99-9f62-fd002ea43311

Dollard, J., Miller, N. E., Doob, L. W., Mowrer, O. H., \& Sears, R. R. (1939). Frustration and Aggression. Yale University Press. https://doi.org/10.1037/10022-000

Donovan, J. (2011). Warning about Working for Shell in Malaysia. Royal Dutch Shell Plc.com.

https://royaldutchshellplc.com/2011/07/17/warning-about-working-for-shell-in-malays ia/

Duffield, C. (2010). Nigeria: "World oil Pollution Capital”. BBC News.

Ellis, E. G. (2016). Bet You Didn't Hear Shell Spilled a Bunch of Oil in the Gulf. WIRED. https://www.wired.com/2016/06/bet-didnt-hear-shell-spilled-bunch-oil-gulf/

Etekpe, A. (2009). Policy Options and Adaptation: A Comprehensive Study of the Niger Delta and Other Deltans of the World. Monograph Series, No.003. Department of Political Science, Niger Delta University.

Friends of the Earth International (2005). Court Orders Oil Companies to Stop Gas Flaring in Nigeria.

Friends of the Earth International (2007). Shell Fails to Stop Nigeria Flaring, Again. https://www.foei.org/press/archive-by-subject/resisting-mining-oil-gas-press/shell-fails -to-stop-nigeria-flaring-again

Frost, E. (2014). CARTHE Drifters: Where Does the Oil Goes When It Is Spilled? OCEAN. https://ocean.si.edu/planet-ocean/tides-currents/carthe-drifters-where-does-oil-go-whe $\underline{\text { n-it-spilled }}$

Gaffey, C. (2017). Nigeria Declares Biafra Group a 'Terrorist' Organisation as a Civil War Fears Grow. Newsweek.

Ibaba, S. I. (2011). Nigeria's Niger Delta: Militia Violence, Amnesty, and Energy Security. Peace and Conflict Studies, 18, 44-78. https://pdfs.semanticscholar.org/a212/058eb3d2d2c3b891c419872a897d936838c4.pdf? $\mathrm{ga}=2.230890648 .621309199 .1578606451-336524035.1576593240$

Iguh, N. (2016). Gas Flaring in Nigeria: An Abridgement of Human/Fundamental Rights. Pinnacle Sociology \& Anthropology, 2, 1057-1063.

Imevbore, V., \& Gundlach, E. (1997). Niger Delta Environmental Survey 1997: Vol. 1 Environmental and Socio-Economic Characteristics. ERML Lagos Nigeria, E-Tech International Inc.

International Crisis Group (2015). Curbing Violence in Nigeria (III): Revisiting the Niger Delta. Africa Report No. 231.

https://d2071andvip0wj.cloudfront.net/231-curbing-violence-in-nigeria-iii-revisiting-t he-niger-delta.pdf

Isumonah, V. A. (2012). Armed Society in the Niger Delta. Armed Forces and Society, 39, 331-358. https://doi.org/10.1177/0095327X12446925

Jupp, V. (2006). The SAGE Dictionary of Social Research Methods. SAGE. https://doi.org/10.4135/9780857020116

Kramer, R. (2014). Climate Change: A State-Corporate Crime Perspective. In T. Spapens, R. White, \& K. Marieke (Eds.), Environmental Crime and Its Victims: Perspectives within Green Criminology. Ashgate.

Krause, R. (2015). Oil Spills Keep Devastating Niger Delta. Environment, All Topics from Climate Change to Conservation. 
Mehra, A. (2012). Shell, Corporate Social Responsibility and Respect for the law. Forbes. https://www.forbes.com/sites/csr/2012/10/03/shell-corporate-social-responsibility-andrespect-for-the-law/

Ministry of Niger Delta Affairs (n.d.). Niger Delta States. https://www.nigerdelta.gov.ng/

Mitee, L. (2012). Oil Exploitation, the Environment and Crimes against Nature. The Vanguard Newspaper.

https://www.vanguardngr.com/2012/03/oil-exploitation-the-environment-and-crimesagainst-nature/

Obasi, N. K. (2003). Foreign Participation in the Nigerian Oil and Gas Industry.

Odalonu, H. B. (2015). The Upsurge of Oil Theft and Illegal Bunkering in the Niger Delta Region of Nigeria: Is There a Way out? Mediterranean Journal of Social Sciences, 6, 563-573.

Oluduro, O. (2014). Oil Exploration and Human Rights Violations in Nigeria's Oil Producing Communities. Intersentia Publishing Ltd.

Omoregie, U. (2016). Sixty Years of Gas Flaring in Nigeria-Science and Policy.

Omotola, S. J. (2009). Liberation Movements and the Rising Violence in the Niger Delta: The New Continuous Site of Oil and Environmental Politics. Studies in Conflict and Terrorism, 33, 36-54. https://doi.org/10.1080/10576100903400597

Orogun, P. S. (2010). Resource Control, Revenue Allocation and Petroleum Politics in Nigeria: The Niger Delta Question. GeoJournal, 75, 459-507. https://doi.org/10.1007/s10708-009-9320-7

Robson, C. (2002). Real World Research: A Resource for Social Scientists and Practitioners-Researchers. Blackwell Publishers.

Sanchex, R. M. L. (2016). Corporate Social Responsibility of Shell. https://rosemeryls112.files.wordpress.com/2016/11/csr-assignment-shell.pdf

Shoraka, S., \& Emmanuel, O. O. (n.d.). Polluted Promises: How Shell Failed to Clean up Ogoniland. War on Want.

Soremekum, K. (2011). Nigeria's Oil Diplomacy and the Management of the Niger Delta Crisis. In C. Obi, \& S. A. Rustad (Eds.), Oil and Insurgency in the Niger Delta: Managing the Complex Politics of Petroviolence (pp. 99-112). Zed Books.

https://doi.org/10.5040/9781350221598.ch-07

Steve, A. (2007). Oil, Gas and Life in Nigeria. Y-Books Ltd.

Steyn, M. S. (2003). Oil Politics in Ecuador and Nigeria: A Perspective from Environmental History on the Struggles between Ethnic Minority Groups, Multinationals Oil Companies and National Governments. Ph.D. Thesis, University of the Free State Bloemfontein.

Tamuno, T. N. (2011). Oil Wars in the Niger Delta 1849-2009. Stirling-Horden Publishers Ltd.

Tickell, O. (2016). 53,000 Nigerian Oil Spill Victims Press New Shell Lawsuits. The Ecologist.

U.S. Non-Governmental Delegation Trip Report (1999). Oil for Nothing: Multinational Corporations, Environmental Destruction, Death and Impunity in the Niger Delta. http://www.essentialaction.org/shell/Final Report.pdf

UN Environment (2017). UNEP Ogoniland Oil Assessment Reveals Extent of Environmental Contamination and Threats to Human Health.

https://www.unenvironment.org/news-and-stories/story/unep-ogoniland-oil-assessme nt-reveals-extent-environmental-contamination-and 
United Nations (1972). Report of the United Nations Conference on the Human Environment, Stockholm, 5-16 June 1972.

https://www.un.org/ga/search/view doc.asp?symbol=A/CONF.48/14/REV.1

United Nations Department of Economic and Social Affairs (2011). Review of Implementation of the Rio Principles.

https://sustainabledevelopment.un.org/content/documents/1127rioprinciples.pdf

United Nations Environment Programme (2011). Environmental Assessment of Ogoniland. https://postconflict.unep.ch/publications/OEA/UNEP OEA.pdf

United Nations Office on Drugs and Crime (2013). Transnational Organized Crime in West Africa: A Threat Assessment.

http://www.unodc.org/documents/data-and-analysis/tocta/West_Africa TOCTA 2013 EN.pdf

Usman, Y. (2017). The Renewal of Hostilities in the Nigerian Delta Region in 2016 and the Failure of the Presidential Amnesty. PhD Thesis, Bangor University.

Vidal, J. (2013). Nigerians Risk Death Working Illegal Oil Refineries. The Guardian. https://www.theguardian.com/global-development/2013/oct/16/poor-nigerians-risk-ref ining-stolen-oil

Walters, R. (2011). Eco Crime and Genetically Modified Food. Routledge. https://doi.org/10.4324/9780203844151

White, R. (2008). Environmental Harm and Crime Prevention. Trends and Issues in Crime and Criminal Justice. Australian Institute of Criminology.

White, R. (2013). The Conceptual Contours of Green Criminology. In R. Walters, S. D. Westerhuis, \& T. Wyatt (Eds.), Emerging Issues in Green Criminology: Exploring Power, Justice and Harm (pp. 17-33). Palgrave Macmillan.

https://doi.org/10.1057/9781137273994 2 